\title{
Fluorinated Carbohydrates as Lectin Ligands: Simultaneous Screening of a Monosaccharide Library and Chemical Mapping by ${ }^{19} \mathrm{~F}$ NMR Spectroscopy
}

\author{
J. Daniel Martínez, Ana I. Manzano, Eva Calviño, Ana de Diego, Borja Rodriguez de Francisco, \\ Cecilia Romanò, Stefan Oscarson, Oscar Millet, Hans-Joachim Gabius, Jesús Jiménez-Barbero,* \\ and Francisco J. Cañada*
}

Cite This: J. Org. Chem. 2020, 85, 16072-16081

Read Online

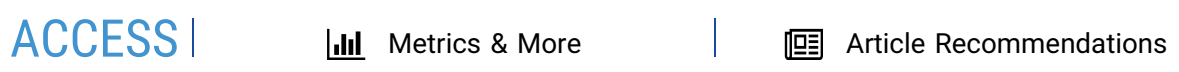

| S1 Supporting Information

ABSTRACT: Molecular recognition of carbohydrates is a key step in essential biological processes. Carbohydrate receptors can distinguish monosaccharides even if they only differ in a single aspect of the orientation of the hydroxyl groups or harbor subtle chemical modifications. Hydroxyl-by-fluorine substitution has proven its merits for chemically mapping the importance of hydroxyl groups in carbohydrate-receptor interactions. ${ }^{19} \mathrm{~F}$ NMR spectroscopy could thus be adapted to allow contact mapping together with screening in compound mixtures. Using a library of fluorinated glucose (Glc), mannose (Man), and galactose (Gal) derived by systematically exchanging every hydroxyl group by a fluorine atom, we developed a strategy combining chemical mapping and ${ }^{19} \mathrm{~F}$ NMR $\mathrm{T}_{2}$ filtering-based screening. By testing this strategy on the proof-of-principle level with a library of 13 fluorinated monosaccharides to a set of three carbohydrate receptors of diverse origin, i.e. the human macrophage galactosetype lectin, a plant lectin, Pisum sativum agglutinin, and the bacterial Gal-/Glc-binding protein from Escherichia coli, it became possible to simultaneously define their monosaccharide selectivity and identify the essential hydroxyls for interaction.

\section{INTRODUCTION}

Molecular recognition events are at the heart of health and disease. From the chemical perspective, understanding the details of interactions for the underlying functional pairings may provide key information for innovative drug discovery and design. In this context, carbohydrate oligomers (saccharides, glycans) are ubiquitous in nature, commonly presented on cell surfaces by protein and lipid scaffolds. ${ }^{1-4}$ Structurally, an exceptionally large diversity can be generated by simply exploiting permutations of linkage points and anomeric position at each glycosidic linkage. ${ }^{5}$ As a consequence, glycans are "ideal for generating compact units with explicit informational properties", 6 and this information is being disclosed to be "read" and "translated" into (patho)physiological processes by lectins. ${ }^{4,5}$ Thus, the analysis of glycan-lectin recognition has become a topic with biomedically promising perspective ${ }^{7,8}$ and a fructiferous foundation to enhance the symbiosis of Chemistry and Biology as Lemieux asked for. ${ }^{9}$

From the molecular recognition perspective, different approaches have been tested to examine the relevance of hydroxyl groups from saccharide units in binding to receptors. One extensively applied approach rests on screening a given set of available closely related saccharides that display different stereochemistry and/or substitutions at a certain site within the sugar ring. ${ }^{10-19}$ This protocol synthetically eliminates or modifies hydroxyl groups (deoxygenation, methylation, exchange by halogens). ${ }^{20}$ In particular, hydroxyl-by-fluorine substitution has been used to trace key hydroxyl groups for contact with either lectins, antibodies, transporters, or enzymes. ${ }^{21}$

Fluorine can be considered as an isosteric mimic of the hydroxyl group, although without the capacity to act as a hydrogen-bond donor and with a diminished hydrogen-bond acceptor competence. ${ }^{2-24}$ Additionally, its particular physicochemical properties ${ }^{25}$ introduce electronic and polarhydrophobic effects. ${ }^{26}$ Indeed, fluorine modulates the population of the conformational space s, $28^{27}$ and lipophilicity of fluorine-containing carbohydrates. ${ }^{29}$ Smart use of these features has already allowed development of new molecules that efficiently act as substrates ${ }^{30}$ and inhibitors of glycosidases. ${ }^{31,32}$ Advances for fluorine introduction into

Special Issue: A New Era of Discovery in Carbohydrate Chemistry

Received: July 30, 2020

Published: December 1, 2020

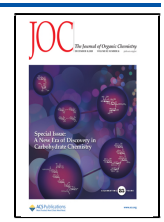


organic molecules have made available a large variety of mono- $^{33}$ and polyfluorinated saccharides, ${ }^{33-40}$ which are highly attractive as chemical probes from different point of views. $^{21}$ It is also well-known that fluorine-containing molecules are extensively used in bioorganic and medicinal chemistry. $^{23,41}$ Many of these studies have driven the development of ${ }^{19} \mathrm{~F}$ NMR-spectroscopy methodologies as valuable tools to study molecular recognition events or to screen compound libraries. ${ }^{42,43}$

In this context, we and others have applied ${ }^{19} \mathrm{~F}$-observed NMR strategies to study glycan-protein interactions by means of saturation transfer difference (STD NMR-spectroscopy) measurements using $1 \mathrm{D}^{44}$ and $2 \mathrm{D}^{34}$ experimental designs, by monitoring chemical shifts perturbations and exchange kinetics, ${ }^{45,46}$ by observing line broadening of the ${ }^{19} \mathrm{~F}$ NMR signals, ${ }^{47-49}$ or by employing relaxation filtering protocols. ${ }^{50,51}$

Herein, we propose a robust and general method to efficiently pick up and study the interactions of a library of fluorinated sugars with a given receptor. By taking advantage of the large chemical shift range of the ${ }^{19} \mathrm{~F}$ nucleus and its sensitivity, monitoring sugar-protein interactions by a panel of 13 different monofluorinated sugars (with up to 26 well resolved ${ }^{19} \mathrm{~F}$ NMR signals considering the presence of the $\alpha$ and $\beta$-anomers for each sugar, Figure 1, Table S1) provides information on the selectivity of the binding event in a single setup. This methodology extends the applicability of the reported $\mathrm{T}_{2}$-filtering strategy and overcomes the limits of ${ }^{1} \mathrm{H}$ NMR resolution (see spectrum in Figure $1 b$ ).

As proof-of-concept, two lectins and a sugar transporter of diverse origins and selectivities have been chosen: the human Macrophage Galactose-type Lectin (MGL, CLEC10A, CD301), a C-type lectin binding $\mathrm{N}$-acetylgalactosamine in $\mathrm{O}$ glycans $\left(\mathrm{T}_{\mathrm{n}}\right.$ antigen, $\left.\mathrm{CD} 175\right)$ and in N-glycans (LacdiNAc); ${ }^{52-54}$ Pisum sativum agglutinin (PSA), a plant lectin selective for $\alpha$-mannopyranosides and -glucopyranosides; ${ }^{15,55}$ and the glucose/galactose-binding protein (GGBP), ${ }^{56-58}$ a bacterial sensor for free monosaccharides. From the analysis of data from simple $1 \mathrm{D}{ }^{19} \mathrm{~F}$ NMR experiments by applying transversal relaxation filters, screening and chemical mapping are simultaneously achieved. In essence, information on the monosaccharide selectivity for a particular sugar receptor is obtained (screening) together with the direct identification of hydroxyls that are essential for binding and those that can be chemically substituted or modified without critically compromising the binding event (chemical mapping).

\section{RESULTS}

Three different types of sugar receptors are deliberately selected herein to illustrate broad applicability, i.e. a human lectin involving $\mathrm{Ca}^{2+}$ for direct ligand contact, a plant agglutinin, and a bacterial sugar transporter.

MGL. MGL belongs to the C-type lectin family characterized by containing a calcium cation at the binding site, directly involved in carbohydrate recognition by coordination bonding. ${ }^{52,53}$ MGL, like the hepatic asialoglycoprotein receptor, is a transmembrane protein with the carbohydrate recognition domain (CRD) on top of its extracellular stalk that oligomerizes to trimers. ${ }^{59}$ GalNAc in $\alpha / \beta$ linkage are the preferred ligands $\left(K_{\mathrm{D}}=12 \mu \mathrm{M}\right.$ for methyl $\alpha$ - $N$-acetylgalactosaminide, $\mathrm{Me} \alpha$-GalNAc), galactose being a weaker binder $\left(K_{\mathrm{D}}=0.9 \mathrm{mM}\right.$ for $\mathrm{Me} \alpha$-Gal $){ }^{53}$ To perform the recognition studies, the soluble extracellular ectodomain containing the CRD was used. It is known that the $\mathrm{Ca}^{2+}$ in

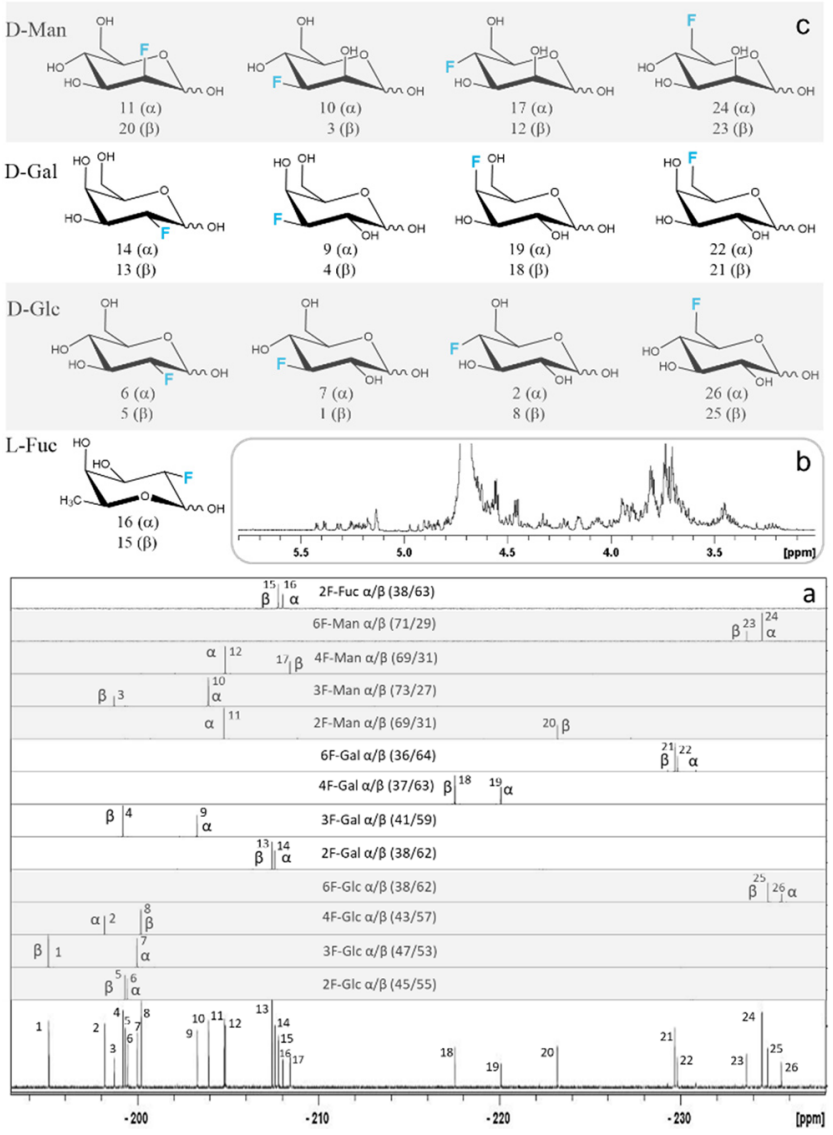

Figure 1. (a) ${ }^{19} \mathrm{~F}$ NMR $\left({ }^{1} \mathrm{H}\right.$-decoupled) spectra recorded for each individual monofluorinated monosaccharide as anomeric mixture. The $\alpha / \beta$ anomeric ratios are given between brackets. Lower panel, ${ }^{19} \mathrm{~F}$ NMR spectrum of the full library. Each peak is numbered from lower to higher field. (b) ${ }^{1} \mathrm{H}$ NMR spectrum of the mixture of the 13 monosaccharides. (c) Representation of the structures of the different monodeoxy-monofluorinated monosaccharides present in the library. The corresponding peak number for each anomer in the ${ }^{19} \mathrm{~F}$ NMR spectrum is indicated.

the binding site makes contact with its Gal/GalNAc ligands through the equatorial/axial $\mathrm{OH}-3$ and $\mathrm{OH}-4$ groups. ${ }^{53}$ In order to study the importance of each hydroxyl group of the Gal moiety, the binding of the four possible monodeoxymonofluorinated Gal analogues (at positions 2, 3, 4, and 6), keeping the anomeric position free, was tested to detect those hydroxyl-to-fluorine substitutions that impair binding. A similar strategy, using an extended mixture of mono- and polyfluorinated galactopyranosides and applying a diversity of techniques, has allowed identification of $\mathrm{OH}-3$ and -4 as the coordinating groups in a calcium-dependent bacterial galactophilic lectin. $^{33}$

Since every monosaccharide exists as a mixture of its $\alpha$ and $\beta$ anomers in equilibrium, eight different molecules are present in solution. The ${ }^{19} \mathrm{~F}$ NMR spectrum of the mixture is pleasingly simple, just showing eight individual ${ }^{19} \mathrm{~F}$ NMR signals (Figure $2 \mathrm{a})$, one for each monofluorinated $\mathrm{Gal}$ anomer in the mixture. Their intensities are governed by the anomer ratio at equilibrium. $^{60}$

The transverse relaxation time $\left(\mathrm{T}_{2}\right)$ for each compound was measured in the free state in the absence of lectin, ranging between 1.2 to $1.8 \mathrm{~s}$ for Gal derivatives (Table S1). The monofluorinated Gal mixture was added to a solution of MGL, 


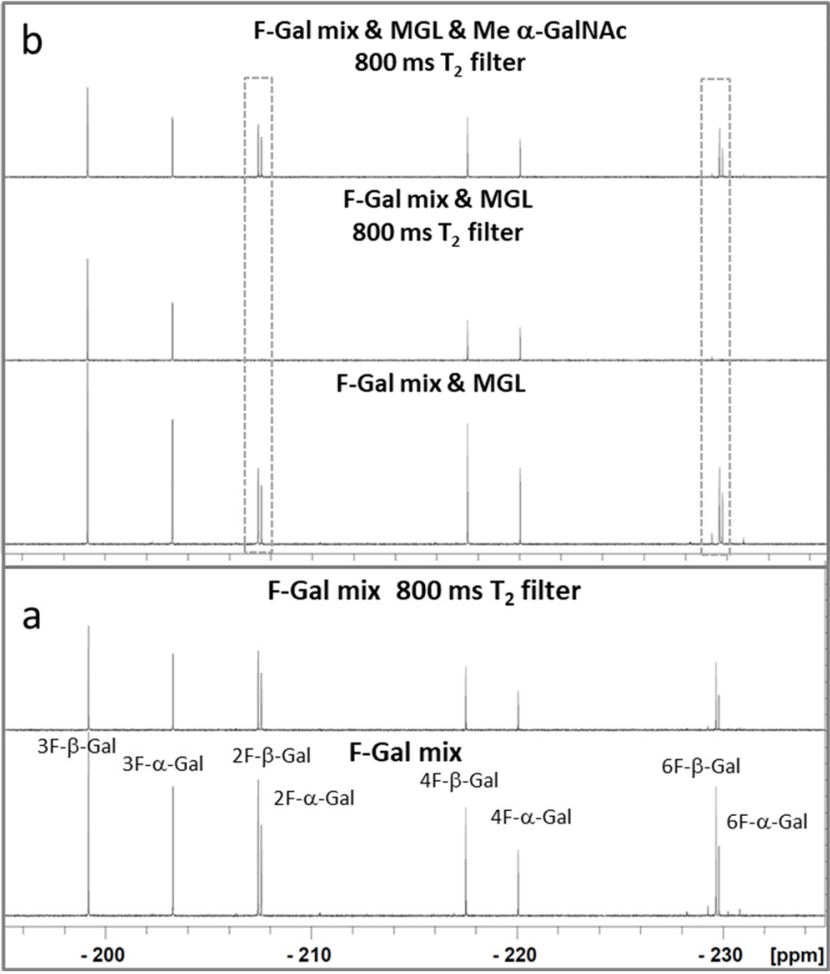

Figure 2. (a) ${ }^{19} \mathrm{~F}$ NMR $\left({ }^{1} \mathrm{H}\right.$-decoupled) spectrum of the F-Galactose mixture (2F-Gal $(0.5 \mathrm{mM})$; 3F-Gal $(0.68 \mathrm{mM})$, $4 \mathrm{~F}-\mathrm{Gal}(0.37 \mathrm{mM})$, and $6 \mathrm{~F}-\mathrm{Gal}(0.45 \mathrm{mM})$ in absence of the protein, without $\mathrm{T}_{2}$ relaxation filter (lower panel), and after applying a $800 \mathrm{~ms} \mathrm{~T}_{2}$ relaxation filter (upper panel). (b) ${ }^{19} \mathrm{~F}$ NMR $\left({ }^{1} \mathrm{H}\right.$-decoupled) spectrum of the same mixture in the presence of $0.015 \mathrm{mM}$ MGL before (lower panel) and after (mid panel) the application of a 800 $\mathrm{ms} \mathrm{T}_{2}$ relaxation filter. The upper panel shows the spectrum after the addition of $0.5 \mathrm{mM} \mathrm{Me} \alpha$-GalNAc with the same relaxation filter.

and the $T_{2}$ filtering strategy ${ }^{50,61,62}$ was applied to identify the binders. Briefly, those molecules that bind to the protein drastically change their hydrodynamic behavior in the bound state, and thus their rotational motion correlation time increases toward that of the large protein, with a concomitant reduction in $\mathrm{T}_{2}$. Additionally, the effective transverse relaxation is also affected by the kinetics of the chemical exchange process between the free and bound states, further reducing the observed $\mathrm{T}_{2}$, especially if the system no longer follows the fast chemical exchange regime. This reduction in $T_{2}$, which is in the first instance manifested in standard 1D NMR spectra as signal broadening, can be easily transformed into a signalintensity reduction by the application of a standard CarrPurcell-Meiboom-Gill (CPMG) spin echo pulse train sequence before acquisition. The filtered NMR spectrum displays the NMR signals of the binders significantly reduced or even suppressed, compared to those of the unbound compounds.

Figure $2 \mathrm{~b}$ shows the comparison of the ${ }^{19} \mathrm{~F}$ NMR spectra recorded for the mixture of monofluorinated galactose derivatives in the presence of MGL (lower panel) with that obtained by applying a spin-echo filter of $800 \mathrm{~ms}$ (central panel). The drastic reduction of the intensity of signals in the presence of protein (Figure $2 b$ central panel) relative to the experiment in its absence (Figure 2a upper panel) corresponding to $2 \mathrm{~F}-\mathrm{Gal}(\beta=2 \%, \alpha=4 \%)$ and $6 \mathrm{~F}-\mathrm{Gal}(\beta=1 \%, \alpha=7 \%)$ is clearly observed, while the NMR signals obtained for 3F-Gal $(\beta=57 \%, \alpha=73 \%)$ and $4 \mathrm{~F}-\mathrm{Gal}(\beta=98 \%, \alpha=80 \%)$ are significantly less altered.

To confirm that this selective signal reduction is due to the binding of the ${ }^{19} \mathrm{~F}$-containing Gal entities to the CRD, a competition experiment was performed by adding $\mathrm{Me} \alpha$ GalNAc to the mixture. The recovery of the 2F-Gal and 6F-Gal signals was evident, indicating that they are displaced from the binding site by the strong competitor (Figure $2 \mathrm{~b}$, upper panel).

Drawing a conclusion from chemical mapping ${ }^{30,49}$ is straightforward: the modification of either hydroxyl at 3 or 4 eliminates a coordination bond in the interaction between sugar and $\mathrm{Ca}^{2+}$. Therefore, the signals corresponding to 3F-Gal and 4F-Gal are not affected by the lectin and do not show significant signal reduction. On the contrary, the hydroxyls at positions 2 and 6 can be substituted by fluorine. Their ${ }^{19} \mathrm{~F}$ NMR signals are clearly reduced in the presence of the MGL due to binding.

Since the broad dispersion of ${ }^{19} \mathrm{~F}$ NMR chemical shifts of the four anomeric pairs of the monofluorinated $\mathrm{Gal}$ analogues is more than $30 \mathrm{ppm}$ (between -199 and $-230 \mathrm{ppm}$ ), the feasibility to test a broad panel of monofluorinated monosaccharides was envisioned. Thus, the four monodeoxymonofluorinated D-glucoses (2F-Glc, 3F-Glc, 4F-Glc, and 6FGlc) and D-mannoses (2F-Man, 3F-Man, 4F-Man, and 6FMan) together with 2-deoxy-2-fluoro-L-fucose (2F-Fuc) were added to provide a library with 13 different anomeric pairs of monofluorinated monosaccharide (Figure 1). All compounds were available from commercial sources except 6F-Man that was chemically synthesized (see Experimental Section).

This mixture with the 13 fluorinated monosaccharide anomeric pairs gives a very crowded ${ }^{1} \mathrm{H}$ NMR spectrum (Figure 1b). In contrast, its proton-decoupled ${ }^{19} \mathrm{~F}$ NMR spectrum presents well-resolved individual signals for each of the 26 different molecules in the sample, which are spread over $40 \mathrm{ppm}$ (Figure 1a). Thus, the extended compound library, including the monofluorinated Gal, Glc, and Man analogues, was now tested with MGL, applying again the $\mathrm{T}_{2}$-filtering strategy (Figure 3). For qualitative visualization of the NMR

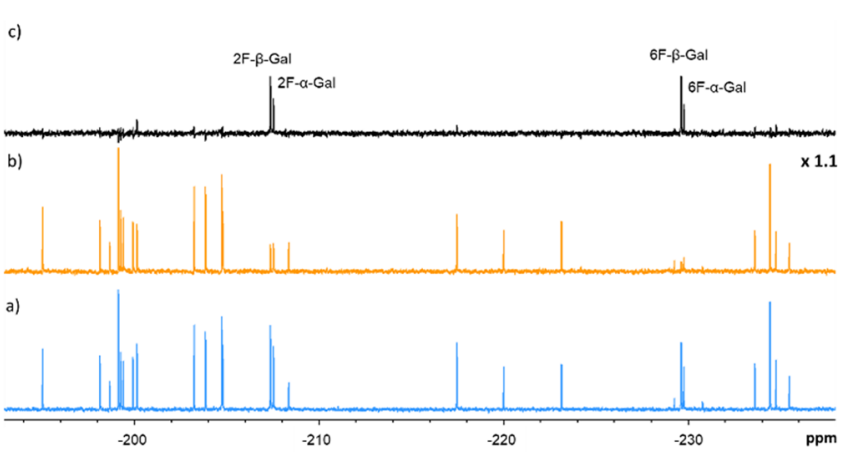

Figure 3. ${ }^{19} \mathrm{~F}$ NMR $\left({ }^{1} \mathrm{H}\right.$-decoupled) $\mathrm{T}_{2}$-filtered spectra recorded for the fluorinated monosaccharide library (Man, Glc, and Gal analogues) in the presence of MGL $(30 \mu \mathrm{M})$. (a) Spectrum acquired with a short $8 \mathrm{~ms} \mathrm{~T}_{2}$ filter. (b) Spectrum acquired with long $160 \mathrm{~ms} \mathrm{~T}_{2}$ filter factored 1.1 times. (c) Difference spectrum.

signals affected by the lectin, the obtained filtered ${ }^{19} \mathrm{~F}$ NMR spectrum was subtracted from the nonfiltered one following the protocol described in the Experimental Section (a correction factor $f$ was applied to the filtered spectrum to account for the signal reduction due to transversal relaxation unrelated with the presence of the protein). Only the ${ }^{19} \mathrm{~F}$ NMR 
signals corresponding to binders should appear in the difference spectrum. Indeed, the peaks corresponding to $2 \mathrm{~F}$ Gal (peaks 13 and 14) and 6F-Gal (peaks 21 and 22) are clearly displayed in the difference spectrum (Figure 3) in accordance with the results of the experiment described above for the smaller sized Gal library.

Given the encouraging results for the first system, the suitability of the monofluorinated monosaccharide library for simultaneous ligand screening and chemical mapping was further tested with two other types of carbohydrate receptors with different sugar selectivities.

PSA. Pisum sativum agglutinin (PSA), a leguminous lectin with a "jelly roll" fold, ${ }^{63}$ was also tested. PSA is selective for Man/Glc-containing oligosaccharides without involvement of $\mathrm{Ca}^{2+}$ in contact with the sugar, but displays weak affinity for single monosaccharides: 0.53 and $1.15 \mathrm{mM}$ for methyl $\alpha$ mannoside (Me $\alpha$-Man) and methyl $\alpha$-glucoside (Me $\alpha$-Glc), respectively. ${ }^{55}$

Several ${ }^{19}$ F NMR peaks diminished (Figure 4a,b) when the $\mathrm{T}_{2}$ filter was applied. Those present in the difference spectrum

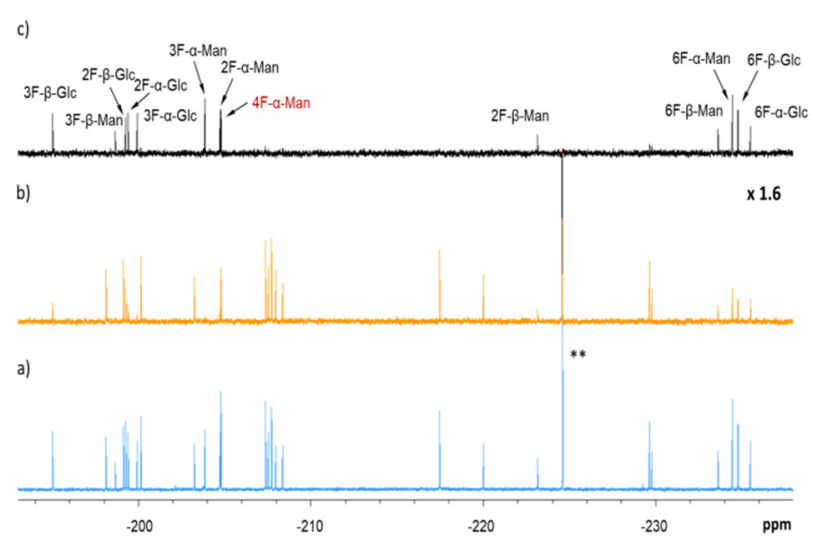

Figure 4. ${ }^{19} \mathrm{~F}$ NMR $\left({ }^{1} \mathrm{H}\right.$-decoupled) $\mathrm{T}_{2}$-filtered spectra recorded for the fluorinated monosaccharide library in the presence of PSA $(25$ $\mu \mathrm{M}$, ligand/protein ratio around 36:1). (a) Spectrum acquired with a short $8 \mathrm{~ms} \mathrm{~T}_{2}$ filter. (b) Spectrum acquired with $720 \mathrm{~ms}$ of $\mathrm{T}_{2}$ filter factored 1.6 times. (c) Difference spectrum. The peak corresponding to $4 \mathrm{~F}-\alpha-\mathrm{Man}$, in red, is a "false positive" (see text). $* * 2$-Fluoroethanol added as internal reference.

(Figure 4c) correspond to 2F-Glc (peaks 5 and 6) and 2F-Man (11 and 20), 3F-Glc (1 and 7), 3F-Man (3 and 10), 6F-Glc (25 and 26), and 6F-Man (23 and 24). Neither 4F-Glc nor any Gal derivatives were observed in the difference ${ }^{19} \mathrm{~F}$ NMR spectrum. However, a limitation of the method was detected. The difference ${ }^{19} \mathrm{~F}$ NMR spectrum also displays "false positives" corresponding to fast relaxing signals (see below), especially when the applied $\mathrm{T}_{2}$ filter is long enough $(720 \mathrm{~ms}$ in this experiment). This was the case for $4 \mathrm{~F}-\alpha$-Man (peak 12, ${ }^{19} \mathrm{~F}_{-} \mathrm{T}_{2 \text {,free }}=0.7 \mathrm{~s}$ ), whose signal relaxation was significantly faster than that of the other signals of the molecules present in the mixture (Table S1).

To confirm specific binding, the difference ${ }^{19} \mathrm{~F}$ NMR spectrum was again complemented with competition experiments (Figure 5) in the presence of a known ligand (Me $\alpha$ Man). The signals corresponding to the $2 \mathrm{~F}-$ and $3 \mathrm{~F}-\mathrm{Man} / \mathrm{Glc}$ derivatives were now clearly observed, indicating that $2 \mathrm{~F}-/ 3 \mathrm{~F}$ Man/Glc are indeed displaced from the binding site by Me $\alpha$ Man. On the contrary, no difference in the intensities of the $4 \mathrm{~F}-\alpha$-Man signal was observed in the absence and presence of
- - PSA, - Me- $\alpha-$ Man - $18 \mathrm{mM}$ Me- $\alpha$-Man $6.3 \mathrm{mM}$ Me- $\alpha-\mathrm{Man}$ - $0 \mathrm{mM}$ Me- $\alpha-\mathrm{Man}$

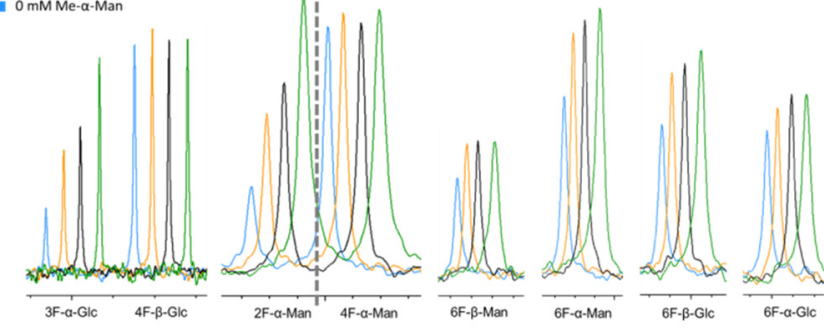

Figure 5. Close-up view of selected ${ }^{19} \mathrm{~F}$ NMR peaks recorded in the ${ }^{19} \mathrm{~F}$ NMR $\mathrm{T}_{2}$-filtered spectra $(720 \mathrm{~ms})$ of the fluorinated monosaccharide library in the absence of lectin (green), in the presence of PSA (blue), and when adding different concentrations of Me $\alpha$-Man.

the competitor (Figure 5), indicating that this molecule is not a binder of the lectin. Very likely, the signal observed in the difference spectrum described above is due to the intrinsic fast relaxation of $4 \mathrm{~F}-\alpha-$ Man $\left({ }^{19} \mathrm{~F}-\mathrm{T}_{2, \text { free }}=0.70 \mathrm{~s}\right.$, Table S1). Analogous results were observed in the absence of the lectin; i.e., $\mathrm{T}_{2}$ of $4 \mathrm{~F}-\mathrm{Man}$ is not affected by the presence of PSA. A mixed situation took place for the 6F-Man and 6F-Glc derivatives (Figure 5). In these cases, the observed signals in the difference experiment are due to ligand binding and to fast relaxation. In fact, the intrinsic $\mathrm{T}_{2 \text {,free }}$ for the corresponding ${ }^{19} \mathrm{~F}$ signals of the $6 \mathrm{~F}-\mathrm{Man}\left({ }^{19} \mathrm{~F}-\mathrm{T}_{2 \text {,free }}=1.00 \mathrm{~s}\right.$ and ${ }^{19} \mathrm{~F}-\mathrm{T}_{2, \text { free }}=0.82$ $\mathrm{s}$ for the $\beta$ and $\alpha$ anomers, respectively) and $6 \mathrm{~F}-\mathrm{Glc}\left({ }^{19} \mathrm{~F}-\mathrm{T}_{2, \text { free }}\right.$ $=0.92 \mathrm{~s}$ and ${ }^{19} \mathrm{~F}_{-} \mathrm{T}_{2, \text { free }}=0.90 \mathrm{~s}$ for the $\beta$ and $\alpha$ anomers, respectively) derivatives is also rather short. On the other side, indeed, the initial decrease in signal intensity induced by the presence of the protein was subtle, but recovery was almost complete after addition of a small concentration of competitor, thus also confirming affinity, although likely weaker.

Interestingly, it has been described that hydroxyls at positions 2 and 3 of glucose can be substituted by fluorine while retaining binding by PSA; however, when $\mathrm{F}$ is at the 6 position the reported binding was minimal and modifications at $\mathrm{OH}-4$ abolished the binding, ${ }^{15,64}$ supporting the results presented here regarding PSA selectivity.

GGBP. The third receptor is the bacterial GGBP. It is involved in chemotaxis and sugar transport in bacteria and has a very high affinity for Glc $(0.04 \mu \mathrm{M})$ and Gal $(0.13 \mu \mathrm{M})^{65,66}$ typical for bacterial binders of free monosaccharides. Its structure consists of two globular Rossman fold domains, and differently from the tested lectins, GGBP presents a deep binding pocket at the hinge connecting and closing both domains around the monosaccharide ligand. ${ }^{56,57}$ When GGBP was added to the monofluorinated monosaccharide library, the signals belonging to Glc and Gal molecules with $\mathrm{F}$ atoms at positions 4 or 6 showed reduced peak intensities in the $T_{2}$ filtered spectrum (Figure 6). On the contrary, those signals corresponding to Glc and Gal moieties substituted at either position 2 or 3 were not affected by the presence of GGBP. This evidence indicates that the $\mathrm{OH}$ groups at those 2 and 3 positions are required for the binding to take place and cannot be substituted by a fluorine atom. In the difference ${ }^{19} \mathrm{~F}$ NMR spectrum, signals for 2F- $\alpha$-Man, 4F- $\alpha$-Man, and 6F- $\alpha$-Man also appear (Figure 6c). However, when Glc was added to the library/receptor mixture as a competitor, the corresponding signals of those fluoromannoses were not recovered (Figure 7). In the cases of $4 \mathrm{~F}-\alpha-\mathrm{Man}$ and $6 \mathrm{~F}-\alpha-\mathrm{Man}$, as for PSA, this 


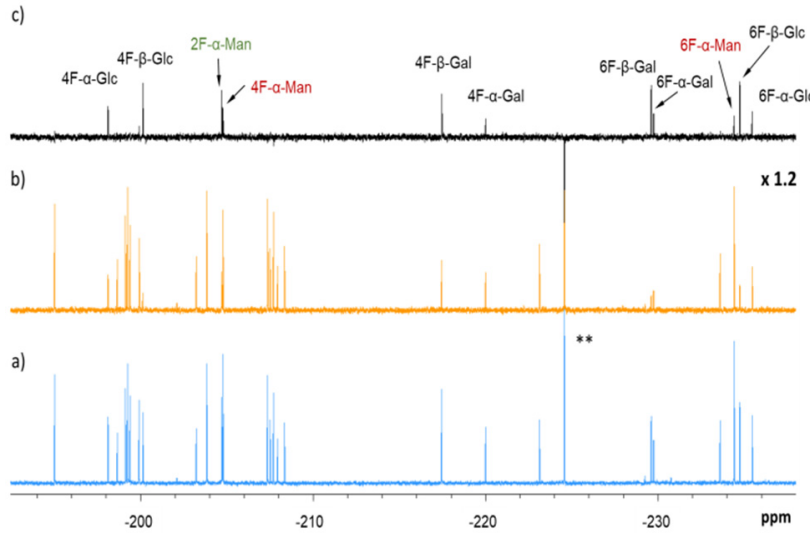

Figure 6. ${ }^{19} \mathrm{~F}$ NMR $\left({ }^{1} \mathrm{H}\right.$-decoupled) $\mathrm{T}_{2}$-filtered spectra recorded for the fluorinated monosaccharide library in the presence of GGBP $(25$ $\mu \mathrm{M}$, ligand/protein ratio ca. 36:1). (a) Spectrum acquired with a short $8 \mathrm{~ms} \mathrm{~T}_{2}$ filter, (b) spectrum acquired with long $400 \mathrm{~ms}$ of $\mathrm{T}_{2}$ filter factored 1.3 times, (c) difference spectrum. For peaks labeled in green and red, see text. **2-Fluoroethanol added as internal reference.

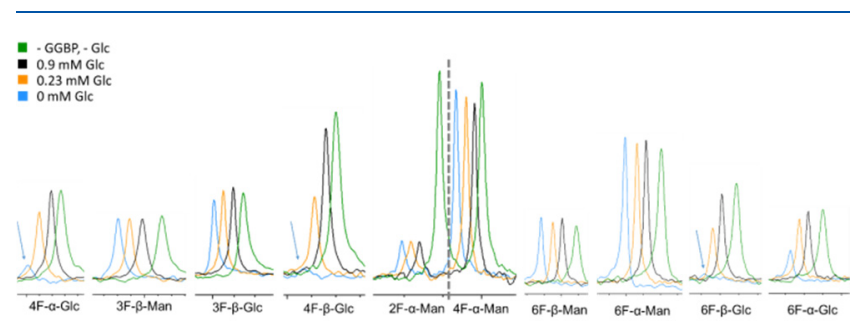

Figure 7. Close-up view of selected ${ }^{19} \mathrm{~F}$ NMR peaks recorded in the ${ }^{19} \mathrm{~F}$ NMR $\mathrm{T}_{2}$-filtered spectra of the fluorinated monosaccharide library in the absence of receptor (green), in the presence of GGBP (blue), and when adding different concentrations of the Glc competitor ( 0.23 $\mathrm{mM}$ orange and $0.9 \mathrm{mM}$ black). In all cases, the NMR experiments were acquired using $720 \mathrm{~ms}$ of $\mathrm{T}_{2}$ filter.

behavior is again due to the intrinsic fast relaxation of the $4 \mathrm{~F}-$ $\alpha$-Man and $6 \mathrm{~F}-\alpha$-Man ${ }^{19} \mathrm{~F}$ signals. Interestingly, $2 \mathrm{~F}-\alpha$-Man is a special case; its signal reduction only takes place in the presence of the protein, and it is not affected by glucose (Figure 7). This result suggests $2 \mathrm{~F}-\alpha$-Man interacts with GGBP but at a location different from the canonical sugarbinding site.

\section{DISCUSSION}

The tested screening method is based on the dramatic differences in transverse relaxation observed for binders within a library of fluorinated monosaccharides, when acquiring NMR spectra in the absence or presence of a carbohydrate-binding protein. The transversal relaxation time is related to the rotational motion correlation time of the molecule, and it sharply decreases as the correlation time increases. When monosaccharides interact with a large receptor, they adopt the correlation time of the macromolecule during the time the complex is associated and, thus, undergo a critical decrease of their $T_{2}$. This change in $T_{2}$ may be followed in a straightforward manner under fast exchange conditions between bound and free states. Thus, only a single ${ }^{19} \mathrm{~F}$ NMR signal appears in the spectrum at the averaged chemical shift of the exchanging states weighted by their corresponding molar fractions. In fact, the observed effective $\mathrm{T}_{2}$ also depends on the kinetics of the exchange between the free and bound forms.
Both rotational motion and exchange effects add together in the $T_{2}$ filtering strategy and allow the efficient detection of medium- to low-affinity binders (from low micromolar to millimolar $K_{\mathrm{D}}$ ), even using high ligand/protein ratios. ${ }^{62}$ The application of the CPMG-based $T_{2}$ filtering scheme is fairly straightforward, and usually a reasonable number of spin-echo loops before acquisition is sufficient to obtain highly sensitive NMR spectra with the required information discriminating binders from nonbinders. From the practical perspective, the current library renders very well resolved ${ }^{19} \mathrm{~F}$ NMR spectra with separated signals for all different monosaccharide moieties in the mixture. Obviously, other fluorinated saccharides could well be added to the mixture increasing the screening power of the concept. As an added value for the ${ }^{19} \mathrm{~F}$ observation, the experiments do not require any deuterated buffer, thus simplifying the experimental setup.

Regarding the screening process, in the first instance, and assuming that all ${ }^{19} \mathrm{~F}$ nuclei in the library have similar $T_{2}$ relaxation times when free in solution, it should be possible to qualitatively visualize those signals that are affected by the protein. To do so, a difference NMR spectrum is obtained by subtracting the spectrum recorded using a short spin-echo delay from a second one measured employing a longer delay. However, the ${ }^{19} \mathrm{~F}$ NMR signals of some molecules, such as $4 \mathrm{~F}$ $\alpha$-Man, 6F- $\alpha / \beta$-Man, and 6F- $\alpha / \beta$-Glc (Table 1), relax significantly faster $\left(T_{2}<1 \mathrm{~s}\right)$ than the others $\left(T_{2}>1.2 \mathrm{~s}\right)$ and their peaks consistently appear in the difference spectrum when long spin-echo relaxation delays are used. Therefore, to unambiguously assess the existence of specific binders at the carbohydrate-binding site, the difference ${ }^{19} \mathrm{~F}$ spectrum should be complemented with the information provided by additional competition experiments carried out by adding a known ligand of the lectin. The comparison of the recovered ${ }^{19} \mathrm{~F}$ NMR signals in the presence of an excess of the competitor in the lectin/library sample can be expressed as the ratio of signal intensities, $I_{t+(\mathrm{C} /-\mathrm{C})}$, measured in spectra acquired with a relaxation filter $t$ in presence $(+C)$ and absence $(-C)$ of competitor (C), thus highlighting the specific binders (Figure 8).

At least qualitatively, these signal recovery data allow the specificities of the three sugar receptors to be distinguished, correlating them with their known monosaccharide selectivity: MGL only recognizes Gal moieties and PSA binds Glc and Gal analogues, while GGBP interacts with Glc and Gal monosaccharides. Additionally, information on the selectivity for the anomeric configuration can be gleaned from the signal recovery data in the $\mathrm{T}_{2}$-filtered competition experiments. For instance, for PSA, the $\alpha$-anomers show a higher recovery ratio than their corresponding $\beta$-anomers in accordance with previous reports. On the contrary, based on X-ray and NMR structural data, GGBP has been described to display specificity for $\beta$-anomers. ${ }^{57}$ The recovery ratio data here presented not only are in agreement with that selectivity but also show that the $\alpha$-anomers are binders, as previously suggested by means of ligand-binding kinetic experiments.

As mentioned above, the $\mathrm{OH}$ by $\mathrm{F}$ substitution has been extensively used in carbohydrate chemistry to map the key hydroxyl groups of a given sugar that are involved in their recognition by lectins, antibodies, transporters, or enzymes. $^{10-20}$ The methodology presented herein, which employs a rationally assembled collection of monofluorinated monossaccharides for which their hydroxyl groups have been systematically substituted by fluorine atoms, allows dissecting 


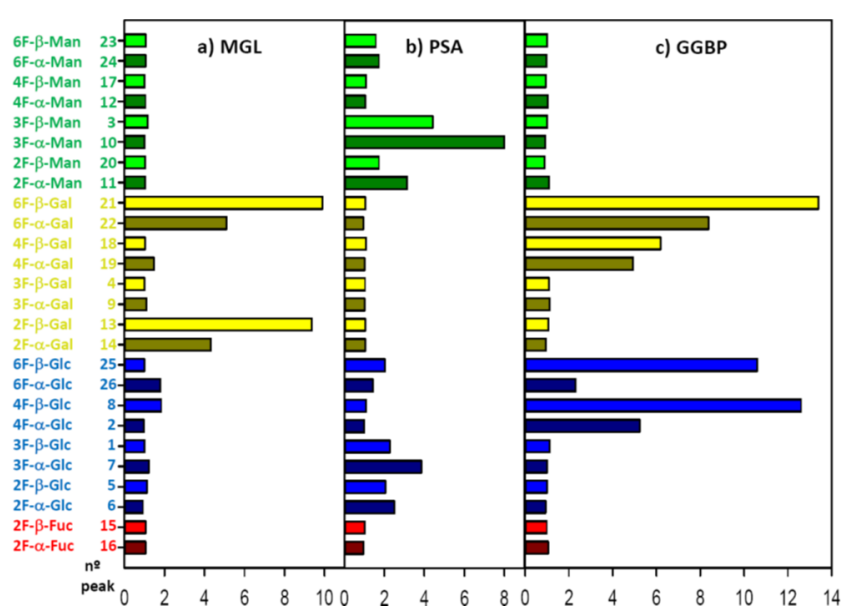

Figure 8. Competition experiments and ${ }^{19} \mathrm{~F}$ NMR $\mathrm{T}_{2}$-filtered spectra for the analysis of the interaction of the fluorinated monosaccharides library with the different lectins. The $x$ axis corresponds to the signal intensity recovery, $I_{t+\mathrm{C} /-\mathrm{C})}$, expressed as the ratio between the relative decay at time $t$ in the presence $(+)$ and absence $(-)$ of competitor (C). From left to right: (a) MGL, $\mathrm{T}_{2}$ filter $t=720 \mathrm{~ms}$. MGL $(30 \mu \mathrm{M})$ and competitor Me $\alpha$-GalNAc $(0.9 \mathrm{mM})$; (b) PSA, T filter $t=720$ ms, PSA $(25 \mu \mathrm{M})$ and competitor Me $\alpha$-Man $(18 \mathrm{mM})$; and (c) GGBP, $\mathrm{T}_{2}$ filter $t=400 \mathrm{~ms}$, GGBP $(25 \mu \mathrm{M})$ and competitor Glc $(0.9$ $\mathrm{mM})$. In all cases the mixture with $0.9 \pm 0.3 \mathrm{mM}$ of each monosaccharide was used.

chemical mapping information regarding the importance of each individual hydroxyl group in the interaction with its receptor. For MGL, the same experiment allows identifying its selectivity for Gal moieties and simultaneously shows that hydroxyls at positions 3 and 4 are essential to keep the interaction ability of the Gal analogue, while hydroxyls 2 and 6 can be modified while still maintaining binding to MGL. PSA can recognize Man and Glc, epimers at position 2. Thus, the orientation of $\mathrm{OH}-2$, axial in Man, equatorial in Glc, is not essential for binding, and consequently, both fluorinated epimers 2F-Man and 2F-Glc are recognized. Moreover, it can be inferred that modifications at $\mathrm{OH}-3$ are tolerated, as $\mathrm{F}$ to $\mathrm{OH}$ substitution at this position does not block binding to the lectin. On the contrary, $\mathrm{OH}-4$ is essential for binding while the modification at position 6 still sustains a weak interaction. Finally, for GGBP, which also recognizes two monosaccharides that share the equatorial configuration at $\mathrm{C} 2$, i.e. Glc and Gal, $\mathrm{OH}-2$ and $\mathrm{OH}-3$ are necessary for binding, while $\mathrm{OH}-4$ (either axial in Gal or equatorial in Glc) and OH-6 can be modified. Thus, the binding pattern is completely opposite to that observed for PSA. Additionally, for GGBP, the possibility of a secondary binding site has been deduced, given the existence of binding to $2 \mathrm{~F}-\alpha$-Man (see Figure 6 ; $2 \mathrm{~F}-\alpha$-Man is marked in green) and the fact that this interaction is not abolished by Glc (see Figure 7 , the signal intensity of $2 \mathrm{~F}-\alpha$-Man is not recovered after addition of Glc), the canonical ligand of GGBP. The implications of this result remain to be explored.

Although $\mathrm{T}_{2}$ filtering has been merely applied herein from a qualitative perspective, the obtained data clearly pave the way to perform further quantitative affinity studies. In fact, such values could be in principle deduced for each isolated monosaccharide from competition experiments, using a competitor with a known affinity constant. ${ }^{67}$

In summary, using this ${ }^{19} \mathrm{~F}$ NMR-based $\mathrm{T}_{2}$-filtering strategy using a library of fluorinated monosaccharides generated through systematic OH-to-F substitutions allows (i) defining sugar selectivity of the tested receptor, (ii) detecting its anomer preference, and (iii) identifying the key hydroxyls for binding, distinguishing them from those that can be chemically modified in the quest to find new binders. Extending this approach to other saccharides (aminosugars and sialosides) and to synthetic libraries of disaccharides will especially be attractive to screen a variety of carbohydrate-receptor families, on the way "from biology to drug target". ${ }^{68}$ In this sense, Siglecs, sialoside receptors proposed to act as "immune cell checkpoints in disease", ${ }^{69}$ or the multifunctional galectins, ${ }^{70,71}$ look like exciting targets to start with. The versatility of the described strategy is evident: it shows applicability to lectins and sensor/transport proteins and proved to be suitable to cover diverse selectivities and wide-ranging affinities, from submicromolar (40 $\mathrm{nM}$ for the Glc-GGBP complex) to over millimolar ( $1.15 \mathrm{mM}$ for the $\mathrm{Me} \beta$-Glc/PSA complex) dissociation constants. Thus, the method is robust and envisioned to find wide application.

\section{EXPERIMENTAL SECTION}

Materials. PSA was from a commercial source (Sigma-AldrichMerck) and dissolved in phosphate-buffered saline at $\mathrm{pH}$ 7.5. MGL ectodomain was recombinantly produced in E. coli and routinely checked for purity and activity as previously described, including ascertaining GalNAc-inhibitable histochemical staining. ${ }^{53,72}$ The samples for NMR were prepared in deuterated Tris buffer (10 $\mathrm{mM})$, containing $\mathrm{CaCl}_{2}(1 \mathrm{mM})$ and $\mathrm{NaCl}(75 \mathrm{mM})$ at $\mathrm{pH} 7.5$ by means of five ultrafiltration-dilution buffer exchange steps with a 10 $\mathrm{kDa}$ cutoff membrane. GGBP was expressed in E. coli and purified as previously described, ${ }^{56}$ and the samples were prepared in $20 \mathrm{mM}$ Tris, containing $150 \mathrm{mM} \mathrm{NaCl}$ and $10 \mathrm{mM} \mathrm{CaCl}_{2}$ at $\mathrm{pH}$ 7.0. Protein concentrations were measured by UV spectrometry.

The monofluorinated monosaccharide mixtures were prepared from concentrated stock solutions of each individual monosaccharide depending on their availability, either commercial or from synthesis. Final concentrations in the mixtures were centered around $0.5 \mathrm{mM}$ or $0.9 \mathrm{mM}$, depending on the experiment, with variations in $\pm 35 \%$ range. Given the intrinsic different equilibrium populations of the different anomers for a given monosaccharide, it is impossible to use the same concentration for each individual species.

Fluorinated Monosaccharides. 2-Deoxy-2-fluoro-glucose, 3deoxy-3-fluoro-glucose, 4-deoxy-4-fluoro-glucose, 6-deoxy-6-fluoroglucose, 2-deoxy-2-fluoro-galactose, 3-deoxy-3-fluoro-galactose, 4deoxy-4-fluoro-galactose, 6-deoxy-6-fluoro-galactose, 2-deoxy-2-fluoro-mannose, 3-deoxy-3-fluoro-mannose, 4-deoxy-4-fluoro-mannose, 2deoxy-2-fluoro-fucose, 2-fluoroethanol, $\mathrm{Me} \alpha$ - $N$-acetylgalactosaminide, and Me $\alpha$-mannopyranoside were from commercial sources (Sigma-Aldrich Merck, Spain; Carbosynth, UK). 6-Deoxy-6-fluoromannose was synthesized as described in the Supporting Information, and its analytical data were consistent with literature values. ${ }^{73}$ Characterizations of the intermediates in reaction steps in the synthesis are described below. NMR peak assignments were made using correlation spectroscopy (COSY) and heteronuclear singlequantum coherence (HSQC).

Methyl 2,3,4-Tri-O-benzoyl-6-deoxy-6-fluoro- $\alpha$-D-mannopyranoside (2). Compound $\mathbf{1}^{74}(50 \mathrm{mg}, 0.098 \mathrm{mmol})$ was dissolved in dry $\mathrm{CH}_{2} \mathrm{Cl}_{2}(1.2 \mathrm{~mL})$, then the solution was cooled to $-78{ }^{\circ} \mathrm{C}$, and DAST ( $98 \mu \mathrm{L}, 0.74 \mathrm{mmol}$ ) was slowly added dropwise. The reaction mixture was kept at $-78{ }^{\circ} \mathrm{C}$ for $30 \mathrm{~min}$, then warmed to rt, and left stirring overnight. The solution was then cooled to $-20{ }^{\circ} \mathrm{C}$, and the reaction was quenched with $\mathrm{MeOH}$. The solvents were evaporated, and the residue was purified by silica gel column chromatography (toluene/EtOAc, 98:2 $\rightarrow$ 8:2, v/v) to give 2 as a yellowish solid (37 $\mathrm{mg}, 0.07 \mathrm{mmol}, 74 \%) . R_{f}=0.8$, toluene/EtOAc $8: 2 ;{ }^{1} \mathrm{H}$ NMR $(400$ $\left.\mathrm{MHz}, \mathrm{CDCl}_{3}\right): \delta 8.14-8.05\left(\mathrm{~m}, 2 \mathrm{H}, \mathrm{H}_{\mathrm{Bz}}\right), 8.02-7.94\left(\mathrm{~m}, 2 \mathrm{H}, \mathrm{H}_{\mathrm{Bz}}\right)$, 7.86-7.78 (m, 2H, $\left.\mathrm{H}_{\mathrm{Bz}}\right), 7.64-7.59\left(\mathrm{~m}, 1 \mathrm{H}, \mathrm{H}_{\mathrm{Bz}}\right), 7.56-7.46(\mathrm{~m}, 3 \mathrm{H}$, $\left.\mathrm{H}_{\mathrm{Bz}}\right), 7.46-7.36\left(\mathrm{~m}, 3 \mathrm{H}, \mathrm{H}_{\mathrm{Bz}}\right), 7.29-7.23\left(\mathrm{~m}, 2 \mathrm{H}, \mathrm{H}_{\mathrm{Bz}}\right), 5.94-5.85$ $(\mathrm{m}, 2 \mathrm{H}, \mathrm{H}-3, \mathrm{H}-4), 5.68$ (dd, $J=3.0,1.8 \mathrm{~Hz}, 1 \mathrm{H}, \mathrm{H}-2), 5.02(\mathrm{~d}, J=$ 
$1.8 \mathrm{~Hz}, 1 \mathrm{H}, \mathrm{H}-1$ ), 4.64 (dt, $J=46.9,3.7 \mathrm{~Hz}, 2 \mathrm{H}, \mathrm{H}-6 \mathrm{ab}), 4.34-4.21$ (m, $1 \mathrm{H}, \mathrm{H}-5), 3.55\left(\mathrm{~s}, 3 \mathrm{H}, \mathrm{OCH}_{3}\right) .{ }^{19} \mathrm{~F}$ NMR $\left(376 \mathrm{MHz} \mathrm{CDCl}_{3}\right): \delta$ $-231.70(\mathrm{td}, J=47.2,22.9 \mathrm{~Hz}$ ). All analytical data were consistent with literature values. ${ }^{74}$

1-O-Acetyl-2,3,4-tri-O-benzoyl-6-deoxy-6-fluoro- $\alpha$-D-mannopyranoside (3). Compound $2(180 \mathrm{mg}, 0.35 \mathrm{mmol})$ was dissolved in $\mathrm{Ac}_{2} \mathrm{O} / \mathrm{AcOH}(2: 1,3.5 \mathrm{~mL}) . \mathrm{H}_{2} \mathrm{SO}_{4}(4 \mu \mathrm{L}, 0.07 \mathrm{mmol})$ was slowly added dropwise at $0{ }^{\circ} \mathrm{C}$, and the mixture was stirred for 5 h. The reaction was then diluted with AcOEt and washed with sat. $\mathrm{NaHCO}_{3}$ (aqueous). The organic layer was dried over $\mathrm{MgSO}_{4}$, filtered, and concentrated. The residue was purified by silica gel flash column chromatography (Toluene/EtOAc, 98:2 $\rightarrow 8: 2$, v/v) to give 3 as a white powder $(150 \mathrm{mg}, 0.28 \mathrm{mmol}, 80 \%) . R_{f}=0.62$, Tol $/$ AcOEt 9:1; $[\alpha]_{\mathrm{D}}^{20}=-64.1\left(c=0.6, \mathrm{CHCl}_{3}\right) ;{ }^{1} \mathrm{H}$ NMR $\left(500 \mathrm{MHz}, \mathrm{CDCl}_{3}\right): \delta$ 8.13-8.06 (m, $\left.2 \mathrm{H}, \mathrm{H}_{\mathrm{Bz}}\right), 8.02-7.94\left(\mathrm{~m}, 2 \mathrm{H}, \mathrm{H}_{\mathrm{Bz}}\right), 7.86-7.77(\mathrm{~m}, 2 \mathrm{H}$, $\left.\mathrm{H}_{\mathrm{Bz}}\right), 7.66-7.60\left(\mathrm{~m}, 1 \mathrm{H}, \mathrm{H}_{\mathrm{Bz}}\right), 7.56-7.52\left(\mathrm{~m}, 1 \mathrm{H}, \mathrm{H}_{\mathrm{Bz}}\right), 7.50(\mathrm{t}, J=$ $\left.7.8 \mathrm{~Hz}, 2 \mathrm{H}, \mathrm{H}_{\mathrm{Bz}}\right), 7.47-7.43\left(\mathrm{~m}, 1 \mathrm{H}, \mathrm{H}_{\mathrm{Bz}}\right), 7.40(\mathrm{t}, J=7.8 \mathrm{~Hz}, 2 \mathrm{H}$, $\left.\mathrm{H}_{\mathrm{Bz}}\right), 7.28\left(\mathrm{t}, J=7.9 \mathrm{~Hz}, 2 \mathrm{H}, \mathrm{H}_{\mathrm{Bz}}\right), 6.39(\mathrm{~d}, J=2.0 \mathrm{~Hz}, 1 \mathrm{H}, \mathrm{H}-1), 5.99$ $(\mathrm{t}, J=10.1 \mathrm{~Hz}, 1 \mathrm{H}, \mathrm{H}-4), 5.92(\mathrm{dd}, J=10.1,3.3 \mathrm{~Hz}, 1 \mathrm{H}, \mathrm{H}-3), 5.72$ (dd, $J=3.4,2.0 \mathrm{~Hz}, 1 \mathrm{H}, \mathrm{H}-2), 4.69-4.56(\mathrm{~m}, 2 \mathrm{H}, \mathrm{H}-6 \mathrm{ab}), 4.34$ (ddt, $J=23.3,10.1,3.2 \mathrm{~Hz}, 1 \mathrm{H}, \mathrm{H}-5), 2.28\left(\mathrm{~s}, 3 \mathrm{H}, \mathrm{OCOCH}_{3}\right) .{ }^{13} \mathrm{C}\left\{{ }^{1} \mathrm{H}\right\}$ NMR $\left(126 \mathrm{MHz}, \mathrm{CDCl}_{3}\right): \delta 168.25\left(\mathrm{O}_{\mathrm{COCH}}\right), 165.70\left(\mathrm{CO}_{\mathrm{Bz}}\right)$, $165.40\left(\mathrm{CO}_{\mathrm{Bz}}\right), 165.35\left(\mathrm{CO}_{\mathrm{Bz}}\right), 133.86\left(\mathrm{C}_{\mathrm{Bz}}\right), 133.78\left(\mathrm{C}_{\mathrm{Bz}}, 133.53\right.$ $\left(\mathrm{C}_{\mathrm{Bz}}\right), 130.13\left(2 \mathrm{C}_{\mathrm{Bz}}\right), 129.94\left(2 \mathrm{C}_{\mathrm{Bz}}\right), 129.89\left(2 \mathrm{C}_{\mathrm{Bz}}\right), 129.02\left(\mathrm{C}_{\mathrm{Bz}}\right)$, $128.89\left(\mathrm{C}_{\mathrm{Bz}}\right), 128.85\left(\mathrm{C}_{\mathrm{Bz}}\right), 128.81\left(2 \mathrm{C}_{\mathrm{Bz}}\right), 128.67\left(2 \mathrm{C}_{\mathrm{Bz}}\right), 128.51$ $\left(2 \mathrm{C}_{\mathrm{Bz}}\right), 90.81(\mathrm{C}-1), 81.34(\mathrm{~d}, J=176.4 \mathrm{~Hz}, \mathrm{C}-6), 71.92(\mathrm{~d}, J=19.3$ $\mathrm{Hz}, \mathrm{C}-5), 69.72(\mathrm{C}-3), 69.30(\mathrm{C}-2), 65.78(\mathrm{~d}, J=7.0 \mathrm{~Hz}, \mathrm{C}-4), 21.11$ $\left(\mathrm{OCOCH}_{3}\right) .{ }^{19} \mathrm{~F}$ NMR $\left(376 \mathrm{MHz}, \mathrm{CDCl}_{3}\right): \delta-232.65(\mathrm{td}, J=47.0$, $23.3 \mathrm{~Hz}$ ). HRMS (ESI-TOF) $m / z[\mathrm{M}+\mathrm{Na}]^{+}$calcd for $\mathrm{C}_{29} \mathrm{H}_{25} \mathrm{FO}_{9} \mathrm{Na}$ 559.1380; found 559.1396.

6-Deoxy-6-fluoro-D-mannose (4). Compound 3 (150 mg, 0.28 $\mathrm{mmol})$ was dissolved in dry $\mathrm{MeOH}(2 \mathrm{~mL})$, and then solid sodium methoxide was added until $\mathrm{pH}=10-11$. The reaction was stirred for $3 \mathrm{~h}$, then quenched with Dowex 50WX8 $\mathrm{H}^{+}$form, filtered, and concentrated. The residue was purified by silica gel flash column chromatography $\left(\mathrm{CH}_{2} \mathrm{Cl}_{2} / \mathrm{MeOH}, 98: 5, \mathrm{v} / \mathrm{v}\right)$ to give 4 as a white solid (40 mg, $0.22 \mathrm{mmol}, 78 \%, \alpha: \beta$ 9:1). $R_{f}=0.2, \mathrm{CH}_{2} \mathrm{Cl}_{2} / \mathrm{MeOH}$ 9:1; ${ }^{1} \mathrm{H}$ NMR (500 MHz, $\left.\mathrm{CD}_{3} \mathrm{OD}\right): \delta 5.11(\mathrm{~d}, J=1.7 \mathrm{~Hz}, 1 \mathrm{H}, \mathrm{H}-1 \alpha)$, 4.73-4.54 (m, 2H, H-6a, H-6b), 3.91 (dddd, $J=26.0,10.0,4.7,2.0$ $\mathrm{Hz}, 1 \mathrm{H}, \mathrm{H}-5$ ), 3.83 (dd, $J=3.4,1.7 \mathrm{~Hz}, 1 \mathrm{H}, \mathrm{H}-2$ ), 3.80 (dd, $J=9.2$, $3.4 \mathrm{~Hz}, 1 \mathrm{H}, \mathrm{H}-3), 3.69(\mathrm{t}, J=9.6 \mathrm{~Hz}, 1 \mathrm{H}, \mathrm{H}-4) .{ }^{19} \mathrm{~F} \mathrm{NMR}(470 \mathrm{MHz}$, $\left.\mathrm{CD}_{3} \mathrm{OD}\right) \delta-233.99(\mathrm{td}, J=47.9,23.8 \mathrm{~Hz}),-234.81(\mathrm{td}, J=47.8$, $25.8 \mathrm{~Hz}$ ). All analytical data were consistent with literature values. ${ }^{73}$

NMR Experiments. All NMR spectra were recorded on a 500 $\mathrm{MHz}$ Bruker spectrometer (470.56 MHz for fluorine) equipped with a ${ }^{19} \mathrm{~F}$ probe $\left({ }^{19} \mathrm{~F},{ }^{1} \mathrm{H}\right.$ SEF from Bruker) at $298 \mathrm{~K}$ in $\mathrm{D}_{2} \mathrm{O}$ unless otherwise is indicated. Standard pulse sequences $1 \mathrm{D}{ }^{1} \mathrm{H}$ with and without decoupling ${ }^{19} \mathrm{~F}$ and $1 \mathrm{D}-{ }^{19} \mathrm{~F}$ with and without decoupling $1 \mathrm{H}$ included in Topspin acquisition software were used. For measuring transversal relaxation times, $T_{2}$, the CPMG pulse sequence was used. $^{75,76}$ It was as follows: [D-90 $0_{x}-\left(\tau-180_{y}-\tau\right)_{n}$-acquire $]$, with a prescan delay of $4 \mathrm{~s}$ and a pre and post $180^{\circ}$ pulse echo delay $\tau$ of 2 ms. The number $n$ of echo loops varies from 2 to 2000, depending on the experiment. The $90_{x}$ and $180_{y}$ pulse durations were calculated for each sample. The total time used for the relaxation filter corresponds to $n$ times the spin echo pulse was applied: $n\left(2 \tau+180_{y}\right)$ (typically between $8 \mathrm{~ms}$ to $8 \mathrm{~s}$ ).

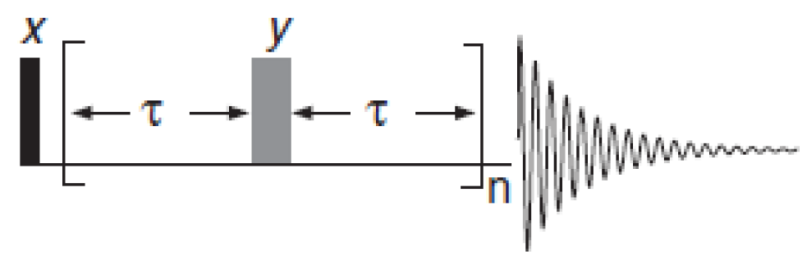

\footnotetext{
${ }^{19} \mathrm{~F}$ was set as the observed nucleus, and proton decoupling was carried out during acquisition using the WALTZ-16 scheme.

Transverse Relaxation Time of F-Monosaccharides. To carry out the relaxation filtered experiments, individual stock solutions
}

around $50 \mathrm{mM}$ in deuterated water of each fluorinated monosaccharide (glucose, galactose, mannose, and L-fucose) were prepared. These stock solutions were appropriately mixed and diluted to the final concentration used in each experiment. The concentrations were estimated by integrating the corresponding signals in the ${ }^{19} \mathrm{~F}$ spectrum. 2-Fluoroethanol was added to the mixture as the internal reference. To prepare the samples of the monosaccharide library in the presence of proteins, 0.2 or $0.5 \mathrm{~mL}$ (for using $2 \mathrm{~mm}$ and $5 \mathrm{~mm}$ NMR tubes, respectively) aliquots of the mixture with $0.9 \mathrm{mM}$ of each fluorinated monosaccharide were dried in a speed-vac, and the resulting powder reconstituted with the same volume of the corresponding buffer with and without protein. $T_{2}$ values were obtained from a series of CPMG experiments recorded with increasing number $n$ (spin echo loops). Experiments with up to 16 different spin echo total relaxation times ranging from 8 to $8000 \mathrm{~ms}$ were determined.

Detection of Ligand Binding by $\mathrm{T}_{2}$-Filtered Experiments. A general protocol was followed using a protein-containing solution with a concentration between $10 \mu \mathrm{M}$ and $30 \mu \mathrm{M}$. The mixtures of monofluorinated monosaccharides were prepapred by mixing aliquots of each monosaccharide from highly concentrated. The final concentration of each monosaccharide in the mixture was around $0.9 \mathrm{mM}([\alpha]+[\beta])$ ranging between 0.6 and $1.2 \mathrm{mM}$ depending their availability. The ligand to protein ratio $(\mathrm{L} / \mathrm{P})$ was maintained between a 20 - to 150 -fold excess, optimized in each case to yield comparable $T_{2}$ decay responses between the three systems (PSA, GGBP, and MGL). CPMG experiments were carried out as previously described, but recording an initial reference experiment with 2 CPMG loops with $\tau=2 \mathrm{~ms}$ ( $8 \mathrm{~ms}$ total relaxation time) and one to five additional experiments with CPMG filters between 16 and 400 CPMG echo loops (64 to $1600 \mathrm{~ms}$, respectively; the exact values of the spectra selected are indicated in each experiment).

In order to obtain the difference spectrum, the $T_{2}$ filtered spectra were multiplied by a factor $f$ to correct the signal decay in the absence of protein. $f$ is defined as the mean value of the ratio of ${ }^{19} \mathrm{~F}$ signal intensities after the first $\left(I_{1}\right)$ and the last $\left(I_{t}\right)$ CPMG experiments for all the fluorinated monosaccharides in the mixture: $f=\bar{I}_{1} / I_{t}$. The first CPMG spectrum is acquired with $t_{1}=8 \mathrm{~ms}$, and the last one at $t=$ 160,720 , and $400 \mathrm{~ms}$ in each case, yielding a factor $f$ of 1.1, 1.6, and 1.2 as shown in Figures 3, 4, and 6, respectively.

Detection of Ligand Binding by Competition Experiments. Competition (displacement) experiments were performed by adding an excess of a cognate sugar to the lectin/monofluorinated monosaccharide mixtures. In particular, $\mathrm{Me} \alpha$-N-acetylgalactosaminide $\left(12 \mu \mathrm{M} \mathrm{K} K_{\mathrm{d}}\right)$ up to $1 \mathrm{mM}$ for $\mathrm{MGL},{ }^{53} \mathrm{Me} \alpha$-mannopyranoside $(530 \mu \mathrm{M})^{55}$ up to $18 \mathrm{mM}$ for PSA, and glucose $(0.04 \mu \mathrm{M})^{65}$ up to 1 $\mathrm{mM}$ for GGBP. Equivalent experiments, with the same CPMG relaxation filter parameters to those used for detection of ligand binding, were carried out to observe recovery in signals that had previously diminished as a consequence of binding. Each experiment was repeated upon sequential addition of the competing ligand.

The signal recovery ratio represented in Figure 8 for each fluorinated monosaccharide in the presence of the lectin after relaxation time $t_{i}, I_{\mathrm{ti}}(+\mathrm{C} /-\mathrm{C})$, with $(+\mathrm{C})$ or without $(-\mathrm{C})$ competitor was calculated from the ratio of relative signal decays in the presence $\left(I_{\mathrm{ti}} / I_{\mathrm{t} 1}\right)_{+\mathrm{C}}$ and in the absence $\left(I_{\mathrm{ti}} / I_{\mathrm{t} 1}\right)_{-\mathrm{C}}$ of competitor for $t_{1}=8 \mathrm{~ms}$ and $t_{i}=720,720$, and $400 \mathrm{~ms}$ for MGL, PSA, and GGBP, respectively.

\section{ASSOCIATED CONTENT}

\section{(s) Supporting Information}

The Supporting Information is available free of charge at https://pubs.acs.org/doi/10.1021/acs.joc.0c01830.

Includes the scheme of synthesis for 6F-Man and characterization spectra of intermediates and final product, the individual ${ }^{19} \mathrm{~F}$ spectra for each monofluorinated monosaccharide, and a table with their ${ }^{19} \mathrm{~F}$ transversal relaxation times. (PDF) 


\section{AUTHOR INFORMATION}

\section{Corresponding Authors}

Jesús Jiménez-Barbero - CIC bioGUNE, Basque Research Technology Alliance, BRTA, 48160 Derio, Spain; Ikerbasque, Basque Foundation for Science, 48009 Bilbao, Spain; Department of Organic Chemistry II, Faculty of Science and Technology, UPV-EHU, 48940 Leioa, Spain; (1) orcid.org/ 0000-0001-5421-8513; Email: jjbarbero@cicbiogune.es

Francisco J. Cañada - Centro de Investigaciones Biológicas Margarita Salas, CSIC, 28040 Madrid, Spain; Centro de Investigación Biomédica en Red-Enfermedades Respiratorias (CIBERES), 28029 Madrid, Spain; ㅇorcid.org/00000003-4462-1469; Email: jcanada@cib.csic.es

\section{Authors}

J. Daniel Martínez - CIC bioGUNE, Basque Research Technology Alliance, BRTA, 48160 Derio, Spain

Ana I. Manzano - Centro de Investigaciones Biológicas Margarita Salas, CSIC, 28040 Madrid, Spain

Eva Calviño - Centro de Investigaciones Biológicas Margarita Salas, CSIC, 28040 Madrid, Spain

Ana de Diego - Centro de Investigaciones Biológicas Margarita Salas, CSIC, 28040 Madrid, Spain

Borja Rodriguez de Francisco - Centro de Investigaciones Biológicas Margarita Salas, CSIC, 28040 Madrid, Spain; (1) orcid.org/0000-0003-4778-313X

Cecilia Romanò - Centre for Synthesis and Chemical Biology, University College Dublin, Belfield, Dublin 4, Ireland

Stefan Oscarson - Centre for Synthesis and Chemical Biology, University College Dublin, Belfield, Dublin 4, Ireland; ○ orcid.org/0000-0002-8273-4918

Oscar Millet - CIC bioGUNE, Basque Research Technology Alliance, BRTA, 48160 Derio, Spain; 이잉.org/00000001-8748-4105

Hans-Joachim Gabius - Institute of Physiological Chemistry, Faculty of Veterinary Medicine, Ludwig-MaximiliansUniversity Munich, 80539 Munich, Germany; 이잉.org/ 0000-0003-3467-3900

Complete contact information is available at:

https://pubs.acs.org/10.1021/acs.joc.0c01830

\section{Funding}

Agencia Estatal de Investigación (Spain) Grants CTQ201564597-C2-1-P and 2-P, RTI2018-094751-B-C21 and C22, Severo Ochoa Excellence Accreditation (SEV-2016-0644) European Research Council (RECGLYCANMR, Advanced Grant No. 788143), and CIBERES, an initiative from the Spanish Institute of Health Carlos III. Science Foundation Ireland, SFI Award 13/LA/1959.

\section{Notes}

The authors declare no competing financial interest.

\section{ACKNOWLEDGMENTS}

We thank Agencia Estatal de Investigación (Spain) for grants CTQ2015-64597-C2-1-P and 2-P, RTI2018-094751-B-C21 and C22, and for FPI fellowship to J.D.M., and for the Severo Ochoa Excellence Accreditation (SEV-2016-0644). J.J.-B. also thanks the European Research Council (RECGLYCANMR, Advanced Grant No. 788143) and CIBERES, an initiative from the Spanish Institute of Health Carlos III. S. O. thanks the SFI Award 13/IA/1959. We acknowledge the access to NMR facility at the CIB Margarita Salas. The referees are acknowledged for helping in improving the manuscript

\section{ABBREVIATIONS}

NMR, nuclear magnetic resonance; CPMG, Carr-PurcellMeiboom-Gill; STD, saturation transfer difference; 1D, onedimensional; MGL, Macrophage Galactose-type Lectin; PSA, Pisum sativum agglutinin; GGBP, glucose/galactose-binding protein; CRD, carbohydrate recognition domain; CLEC, CType lectin; CD, cluster of differentiation

\section{REFERENCES}

(1) Ginsburg, V.; Neufeld, E. F. Complex Heterosaccharides of Animals. Annu. Rev. Biochem. 1969, 38, 371.

(2) Varki, A. Biological roles of glycans. Glycobiology 2017, 27, 3.

(3) Gagneux, P.; Aebi, M.; Varki, A. In Essentials of Glycobiology, 3rd ed.; Varki A, C. R., Esko, J. D., et al., Eds.; Cold Spring Harbor Laboratory Press: Cold Spring Harbor (NY), 2017; p 253.

(4) Kaltner, H.; Abad-Rodriguez, J.; Corfield, A. P.; Kopitz, J.; Gabius, H.-J. The sugar code: letters and vocabulary, writers, editors and readers and biosignificance of functional glycan-lectin pairing. Biochem. J. 2019, 476, 2623.

(5) Böhm, M.; Bohne-Lang, A.; Frank, M.; Loss, A.; Rojas-Macias, M. A.; Lütteke, T. Glycosciences.DB: an annotated data collection linking glycomics and proteomics data (2018 update). Nucleic Acids Res. 2019, 47, D1195.

(6) Winterburn, P. J.; Phelps, C. F. The Significance of Glycosylated Proteins. Nature 1972, 236, 147.

(7) Solís, D.; Bovin, N. V.; Davis, A. P.; Jiménez-Barbero, J.; Romero, A.; Roy, R.; Smetana, K., Jr.; Gabius, H.-J. A guide into glycosciences: How chemistry, biochemistry and biology cooperate to crack the sugar code. Biochim. Biophys. Acta, Gen. Subj. 2015, 1850, 186.

(8) Agre, P.; Bertozzi, C.; Bissell, M.; Campbell, K. P.; Cummings, R. D.; Desai, U. R.; Estes, M.; Flotte, T.; Fogleman, G.; Gage, F.; Ginsburg, D.; Gordon, J. I.; Hart, G.; Hascall, V.; Kiessling, L.; Kornfeld, S.; Lowe, J.; Magnani, J.; Mahal, L. K.; Medzhitov, R.; Roberts, R. J.; Sackstein, R.; Sarkar, R.; Schnaar, R.; Schwartz, N.; Varki, A.; Walt, D.; Weissman, I. Training the next generation of biomedical investigators in glycosciences. J. Clin. Invest. 2016, 126, 405.

(9) Lemieux, R. U. Toward Enhanced symbiosis of Chemistry and Biology. FASEB J. 1994, 8, 273.

(10) Bessell, E. M.; Foster, A. B.; Westwood, J. H. The use of deoxyfluoro-D-glucopyranoses and related compounds in a study of yeast hexokinase specificity. Biochem. J. 1972, 128, 199.

(11) Glaudemans, C. P. J. Mapping of subsites of monoclonal anticarbohydrate antibodies using deoxy and deoxyfluorosugars. Chem. Rev. 1991, 91, 25.

(12) Fernández, P.; Jiménez-Barbero, J.; Martín-Lomas, M. Synthesis of all the possible monomethyl ethers and several deoxyhaloanalogs of methyl n-lactoside as ligands for the Ricinus communis lectins. Carbohydr. Res. 1994, 254, 61.

(13) Hevey, R. Bioisosteres of carbohydrate functional groups in glycomimetic design. Biomimetics 2019, 4, 53.

(14) Barnett, J. E. G.; Holman, G. D.; Munday, K. A. Structural requirements for binding to sugar-transport system of human erythrocyte. Biochem. J. 1973, 131, 211.

(15) Vanwauwe, J. P.; Loontiens, F. G.; Debruyne, C. K. Carbohydrate binding specificity of lectin from pea (Pisum sativum). Biochim. Biophys. Acta, Protein Struct. 1975, 379, 456.

(16) Bhattacharyya, L.; Brewer, C. F. Lectin-carbohydrate interactions. Studies of the nature of hydrogen-bonding between Dgalactose and certain D-galactose-specific lectins, and between Dmannose and concanavalin-A. Eur. J. Biochem. 1988, 176, 207.

(17) Withers, S. G.; Street, I. P.; Percival, M. D. Fluorinated carbohydrates as probes of enzyme specificity and mechanism. ACS Symp. Ser. 1988, 374, 59. 
(18) Nycholat, C. M.; Bundle, D. R. Synthesis of monodeoxy and mono-O-methyl congeners of methyl beta-D-mannopyranosyl-(1 -> 2)-beta-D-mannopyranoside for epitope mapping of anti-Candida albicans antibodies. Carbohydr. Res. 2009, 344, 555.

(19) McCarter, J. D.; Adam, M. J.; Withers, S. G. Binding energy and catalysis. Fluorinated and deoxygenated glycosides as mechanistics probes of Escherichia-coli (LacZ) $\beta$-galactosidase. Biochem. J. 1992, 286, 721.

(20) Lemieux, R. U. The origin of the specificity in the recognition of oligosaccharides by proteins. Chem. Soc. Rev. 1989, 18, 347.

(21) Linclau, B.; Ardá, A.; Reichardt, N.-C.; Sollogoub, M.; Unione, L.; Vincent, S. P.; Jiménez-Barbero, J. Fluorinated carbohydrates as chemical probes for molecular recognition studies. Current status and perspectives. Chem. Soc. Rev. 2020, 49, 3863.

(22) Bégué, J.-P.; Bonnet-Delpon, D. 1. Bioorganic and medicinal chemistry of fluorine; John Wiley \& Sons: Hoboken, NJ, 2008.

(23) Gillis, E. P.; Eastman, K. J.; Hill, M. D.; Donnelly, D. J.; Meanwell, N. A. Applications of Fluorine in Medicinal Chemistry. J. Med. Chem. 2015, 58, 8315.

(24) Dalvit, C.; Invernizzi, C.; Vulpetti, A. Fluorine as a hydrogenbond acceptor: experimental evidence and computational calculations. Chem. Eur. J. 2014, 20, 11058.

(25) Dunitz, J. D. Organic fluorine: odd man out. ChemBioChem 2004, 5, 614.

(26) Biffinger, J. C.; Kim, H. W.; DiMagno, S. G. The polar hydrophobicity of fluorinated compounds. ChemBioChem 2004, 5, 622.

(27) Unione, L.; Xu, B.; Díaz, D.; Martín-Santamaría, S.; Poveda, A.; Sardinha, J.; Rauter, A. P.; Bleriot, Y.; Zhang, Y.; Cañada, F. J.; Sollogoub, M.; Jiménez-Barbero, J. Conformational Plasticity in Glycomimetics: Fluorocarbamethyl-L-idopyranosides Mimic the Intrinsic Dynamic Behaviour of Natural Idose Rings. Chem. - Eur. J. 2015, 21, 10513.

(28) St-Gelais, J.; Côté, É.; Lainé, D.; Johnson, P. A.; Giguère, D. Addressing the Structural Complexity of Fluorinated Glucose Analogues: Insight into Lipophilicities and Solvation Effects. Chem. - Eur. J. 2020, DOI: 10.1002/chem.202002825.

(29) Linclau, B.; Wang, Z.; Compain, G.; Paumelle, V.; Fontenelle, C. Q.; Wells, N.; Weymouth-Wilson, A. Investigating the Influence of (Deoxy) fluorination on the Lipophilicity of Non-UV-Active Fluorinated Alkanols and Carbohydrates by a New $\log \mathrm{P}$ Determination Method. Angew. Chem., Int. Ed. 2016, 55, 674.

(30) Williams, S. J.; Withers, S. G. Glycosyl fluorides in enzymatic reactions. Carbohydr. Res. 2000, 327, 27.

(31) Withers, S. G.; Street, I. P.; Bird, P.; Dolphin, D. H. 2-Deoxy-2Fluoroglycosides. A Novel Class of Mechanism-Based Glucosidase Inhibitors. J. Am. Chem. Soc. 1987, 109, 7530.

(32) Tysoe, C.; Withers, S. G. Fluorinated Mechanism-Based Inhibitors: Common Themes and Recent Developments. Curr. Top. Med. Chem. 2014, 14, 865.

(33) Denavit, V.; Laine, D.; Bouzriba, C.; Shanina, E.; Gillon, E.; Fortin, S.; Rademacher, C.; Imberty, A.; Giguere, D. Stereoselective Synthesis of Fluorinated Galactopyranosides as Potential Molecular Probes for Galactophilic Proteins: Assessment of Monofluorogalactoside-LecA Interactions. Chem. - Eur. J. 2019, 25, 4478.

(34) Diercks, T.; Infantino, A. S.; Unione, L.; Jiménez-Barbero, J.; Oscarson, S.; Gabius, H.-J. Fluorinated Carbohydrates as Lectin Ligands: Synthesis of OH/F-Substituted N-Glycan Core Trimannoside and Epitope Mapping by 2D STD-TOCSYreF NMR spectroscopy. Chem. - Eur. J. 2018, 24, 15761.

(35) N’Go, I.; Golten, S.; Arda, A.; Cañada, F. J.; Jiménez-Barbero, J.; Linclau, B.; Vincent, S. P. Tetrafluorination of Sugars as Strategy for Enhancing Protein-Carbohydrate Affinity: Application to UDPGalp Mutase Inhibition. Chem. Eur. J. 2014, 20, 106.

(36) Cheng, Y.; Guo, A.-L.; Guo, D.-S. Recent Progress in Synthesis and Applications of Fluorinated Carbohydrates. Curr. Org. Chem. 2010, 14, 977.

(37) Uhrig, M. L.; Lantano, B.; Postigo, A. Synthetic strategies for fluorination of carbohydrates. Org. Biomol. Chem. 2019, 17, 5173.
(38) Card, P. J. Synthesis of fluorinated carbohydrates. J. Carbohydr. Chem. 1985, 4, 451.

(39) Dax, K.; Albert, M.; Ortner, J.; Paul, B. J. Synthesis of deoxyfluoro sugars from carbohydrate precursors. Carbohydr. Res. 2000, 327, 47.

(40) Denavit, V.; Laine, D.; St-Gelais, J.; Johnson, P. A.; Giguere, D. A Chiron approach towards the stereoselective synthesis of polyfluorinated carbohydrates. Nat. Commun. 2018, 9, 11.

(41) Wang, J.; Sanchez-Rosello, M.; Acena, J. L.; del Pozo, C.; Sorochinsky, A. E.; Fustero, S.; Soloshonok, V. A.; Liu, H. Fluorine in pharmaceutical industry: fluorine-containing drugs introduced to the market in the last decade (2001-2011). Chem. Rev. 2014, 114, 2432.

(42) Dalvit, C. Ligand- and substrate-based ${ }^{19} \mathrm{~F}$ NMR screening: Principles and applications to drug discovery. Prog. Nucl. Magn. Reson. Spectrosc. 2007, 51, 243.

(43) Dalvit, C.; Vulpetti, A. Ligand-Based Fluorine NMR Screening: Principles and Applications in Drug Discovery Projects. J. Med. Chem. 2019, 62, 2218.

(44) Diercks, T.; Ribeiro, J. P.; Cañada, F. J.; André, S.; JiménezBarbero, J.; Gabius, H.-J. Fluorinated Carbohydrates as Lectin Ligands: Versatile Sensors in ${ }^{19} \mathrm{~F}$-Detected Saturation Transfer Difference NMR Spectroscopy. Chem. Eur. J. 2009, 15, 5666.

(45) Matei, E.; Andre, S.; Glinschert, A.; Infantino, A. S.; Oscarson, S.; Gabius, H.-J.; Gronenborn, A. M. Fluorinated Carbohydrates as Lectin Ligands: Dissecting Glycan-Cyanovirin Interactions by Using F-19 NMR Spectroscopy. Chem. Eur. J. 2013, 19, 5364.

(46) Shishmarev, D.; Fontenelle, C. Q.; Kuprov, I.; Linclau, B.; Kuchel, P. W. Transmembrane Exchange of Fluorosugars: Characterization of Red Cell GLUT1 Kinetics Using(19)F NMR. Biophys. J. 2018, 115, 1906

(47) Unione, L.; Alcala, M.; Echeverría, B.; Serna, S.; Arda, A.; Franconetti, A.; Cañada, F. J.; Diercks, T.; Reichardt, N.; JiménezBarbero, J. Fluoroacetamide Moieties as NMR Spectroscopy Probes for the Molecular Recognition of GlcNAc-Containing Sugars: Modulation of the CH-p Stacking Interactions by Different Fluorination Patterns. Chem. Eur. J. 2017, 23, 3957.

(48) Katiyar, S.; Singh, A.; Surolia, A. The interaction of Ntrifluoroacetylgalactosamine and its derivatives with winged bean (Psophocarpus tetragonolobus) basic agglutinin reveals differential mechanism of their recognition: a fluorine-19 nuclear magnetic resonance study. Glycoconjugate J. 2014, 31, 537.

(49) Krishna Sastry, M. V.; Swamy, M. J.; Surolia, A. Analysis of dynamics and mechanism of ligand binding to Artocarpus integrifolia agglutinin. $\mathrm{A}^{13} \mathrm{C}$ and ${ }^{19} \mathrm{~F}$ NMR study. J. Biol. Chem. 1988, 263, 14826.

(50) Martínez, J. D.; Valverde, P.; Delgado, S.; Romano, C.; Linclau, B.; Reichardt, N. C.; Oscarson, S.; Arda, A.; Jiménez-Barbero, J.; Cañada, F. J. Unraveling Sugar Binding Modes to DC-SIGN by Employing Fluorinated Carbohydrates. Molecules 2019, 24, 2337.

(51) Wamhoff, E. C.; Hanske, J.; Schnirch, L.; Aretz, J.; Grube, M.; Silva, D. V.; Rademacher, C. F-19 NMR-Guided Design of Glycomimetic Langerin Ligands. ACS Chem. Biol. 2016, 11, 2407.

(52) van Vliet, S. J.; Saeland, E.; van Kooyk, Y. Sweet preferences of MGL: carbohydrate specificity and function. Trends Immunol. 2008, $29,83$.

(53) Marcelo, F.; García-Martín, F.; Matsushita, T.; Sardinha, J.; Coelho, H.; Oude-Vrielink, A.; Koller, C.; Andre, S.; Cabrita, E. J.; Gabius, H.-J.; Nishimura, S.-I.; Jiménez-Barbero, J.; Cañada, F. J. Delineating Binding Modes of Gal/GalNAc and Structural Elements of the Molecular Recognition of Tumor-Associated Mucin Glycopeptides by the Human Macrophage Galactose-Type Lectin. Chem. Eur. J. 2014, 20, 16147.

(54) Pirro, M.; Rombouts, Y.; Stella, A.; Neyrolles, O.; BurletSchiltz, O.; van Vliet, S. J.; de Ru, A. H.; Mohammed, Y.; Wuhrer, M.; van Veelen, P. A.; Hensbergen, P. J. Characterization of Macrophage Galactose-type Lectin (MGL) ligands in colorectal cancer cell lines. Biochim. Biophys. Acta, Gen. Subj. 2020, 1864, 129513.

(55) Schwarz, F. P.; Puri, K. D.; Bhat, R. G.; Surolia, A. Thermodynamics of monosaccharide binding to concanavalin $\mathrm{A}$, 
pea (Pisum-sativum) lectin, and lentil (Lens-culinaris) lectin. J. Biol. Chem. 1993, 268, 7668.

(56) Ortega, G.; Castaño, D.; Diercks, T.; Millet, O. Carbohydrate Affinity for the Glucose-Galactose Binding Protein Is Regulated by Allosteric Domain Motions. J. Am. Chem. Soc. 2012, 134, 19869.

(57) Borrok, M. J.; Kiessling, L. L.; Forest, K. T. Conformational changes of glucose/galactose-binding protein illuminated by open, unliganded, and ultra-high-resolution ligand-bound structures. Protein Sci. 2007, 16, 1032.

(58) Johan; Mowbray, S. L. Sugar Recognition by a Glucose/ Galactose Receptor. Evaluation of Binding Energetics from Molecular Dynamics Simulations. J. Biol. Chem. 1995, 270, 9978.

(59) Jégouzo, S. A. F.; Quintero-Martínez, A.; Ouyang, X.; dos Santos, A.; Taylor, M. E.; Drickamer, K. Organization of the extracellular portion of the macrophage galactose receptor: a trimeric cluster of simple binding sites for $\mathrm{N}$-acetylgalactosamine. Glycobiology 2013, 23, 853.

(60) Kerins, L.; Byrne, S.; Gabba, A.; Murphy, P. V. Anomer Preferences for Glucuronic and Galacturonic Acid and Derivatives and Influence of Electron-Withdrawing Substituents. J. Org. Chem. 2018, 83, 7714 .

(61) Hajduk, P. J.; Olejniczak, E. T.; Fesik, S. W. One-dimensional relaxation- and diffusion-edited NMR methods for screening compounds that bind to macromolecules. J. Am. Chem. Soc. 1997, $119,12257$.

(62) Dalvit, C.; Piotto, M. F-19 NMR transverse and longitudinal relaxation filter experiments for screening: a theoretical and experimental analysis. Magn. Reson. Chem. 2017, 55, 106.

(63) Srinivas, V. R.; Reddy, G. B.; Ahmad, N.; Swaminathan, C. P.; Mitra, N.; Surolia, A. Legume lectin family, the 'natural mutants of the quaternary state', provide insights into the relationship between protein stability and oligomerization. Biochim. Biophys. Acta, Gen. Subj. 2001, 1527, 102.

(64) Schwarz, F. P.; Misquith, S.; Surolia, A. Effect of substituent on the thermodynamics of D-glucopyranoside binding to concanavalin A, pea (Pisum sativum) lectin and lentil (Lens culinaris) lectin. Biochem. J. 1996, 316 (Pt 1), 123.

(65) Miller, D. M.; Olson, J. S.; Quiocho, F. A. The Mechanism of Sugar binding to the Periplasmic Receptor for Galactose Chemotaxis and Transport in Escherichia coli. J. Biol. Chem. 1980, 255, 2465.

(66) Vyas, M. N.; Vyas, N. K.; Quiocho, F. A. Crystallographic analysis of the epimeric and anomeric specificity of the periplasmic transport/chemosensory protein receptor for D-glucose and Dgalactose. Biochemistry 1994, 33, 4762.

(67) Dalvit, C.; Parent, A.; Vallée, F.; Mathieu, M.; Rak, A. Fast NMR Methods for Measuring in the Direct and/or Competition Mode the Dissociation Constants of Chemical Fragments Interacting with a Receptor. ChemMedChem 2019, 14, 1115.

(68) O’Sullivan, J. A.; Chang, A. T.; Youngblood, B. A.; Bochner, B. S. Eosinophil and mast cell Siglecs: From biology to drug target. J. Leukocyte Biol. 2020, 108, 73.

(69) Duan, S.; Paulson, J. C. Siglecs as Immune Cell Checkpoints in Disease. Annu. Rev. Immunol. 2020, 38, 365.

(70) Garcia Caballero, G.; Kaltner, H.; Kutzner, T. J.; Ludwig, A.-K.; Manning, J. C.; Schmidt, S.; Sinowatz, F.; Gabius, H.-J. How galectins have become multifunctional proteins. Histol. Histopathol. 2020, 35, 509.

(71) Ludwig, A.-K.; Michalak, M.; Xiao, Q.; Gilles, U.; Medrano, F. J.; Ma, H.; FitzGerald, F. G.; Hasley, W. D.; Melendez-Davila, A.; Liu, M.; Rahimi, K.; Kostina, N. Y.; Rodriguez-Emmenegger, C.; Moeller, M.; Lindner, I.; Kaltner, H.; Cudic, M.; Reusch, D.; Kopitz, J.; Romero, A.; Oscarson, S.; Klein, M. L.; Gabius, H.-J.; Percec, V. Design-functionality relationships for adhesion/growth-regulatory galectins. Proc. Natl. Acad. Sci. U. S. A. 2019, 116, 2837.

(72) Kaltner, H.; Manning, J. C.; Caballero, G. G.; Di Salvo, C.; Gabba, A.; Romero-Hernandez, L. L.; Knospe, C.; Wu, D.; Daly, H. C.; O'Shea, D. F.; Gabius, H.-J.; Murphy, P. V. Revealing biomedically relevant cell and lectin type-dependent structure-activity profiles for glycoclusters by using tissue sections as an assay platform. RSC Adv. 2018, 8, 28716

(73) Khedri, Z.; Muthana, M. M.; Li, Y.; Muthana, S. M.; Yu, H.; Cao, H.; Chen, X. Probe sialidase substrate specificity using chemoenzymatically synthesized sialosides containing C9-modified sialic acid. Chem. Commun. 2012, 48, 3357.

(74) Esmurziev, A. M.; Simic, N.; Hoff, B. H.; Sundby, E. Synthesis and Structure Elucidation of Benzoylated Deoxyfluoropyranosides. J. Carbohydr. Chem. 2010, 29, 348.

(75) Carr, H. Y.; Purcell, E. M. Effects of Diffusion on Free Precession in Nuclear Magnetic Resonance Experiments. Phys. Rev. 1954, 94, 630.

(76) Meiboom, S.; Gill, D. Modified Spin-Echo Method for Measuring Nuclear Relaxation Times. Rev. Sci. Instrum. 1958, 29, 688. 